\title{
Labour
}

Journal of Canadian Labour Studies

Le Travail

Revue d'Études Ouvrières Canadiennes

\section{Tina Loo, Moved by the State: Forced Relocation and Making a Good Life in Post War Canada (Vancouver: UBC Press 2019)}

\section{Martha Walls}

Volume 86, automne 2020

URI : https://id.erudit.org/iderudit/1074482ar

DOI : https://doi.org/10.1353/1lt.2020.0046

Aller au sommaire du numéro

Éditeur(s)

Canadian Committee on Labour History

ISSN

0700-3862 (imprimé)

1911-4842 (numérique)

Découvrir la revue

Citer ce compte rendu

Walls, M. (2020). Compte rendu de [Tina Loo, Moved by the State: Forced Relocation and Making a Good Life in Post War Canada (Vancouver: UBC Press 2019)]. Labour / Le Travail, 86, 191-193. https://doi.org/10.1353/ltt.2020.0046 d'utilisation que vous pouvez consulter en ligne. 


\section{REVIEWS / COMPTES RENDUS}

Tina Loo, Moved by the State: Forced Relocation and Making a Good Life in Post War Canada (UBC Press: Vancouver 2019)

Tina Loo's Moved by the State: Forced Relocation and Making a Good Life in Post War Canada explores state efforts to alleviate poverty and expand its power in Canada during the 1950s-1970s. Loo's book considers how this dual agenda was sought via a series of five relocation initiatives in Canada: Newfoundland's fishing outports, Inuit communities in the central arctic, parishioners of Quebec's Lower St. Lawrence and Gaspé regions, Africville in Halifax, and Vancouver's East side community of Strathcona. Federal, provincial, and municipal governments undertook relocation programs that were not ends in and of themselves but rather they were part of broader programmes of government intervention, economic growth, and community development. These served to harness poor people themselves in identifying and remedying social and economic problems and in shoring up the authority of the state.

Loo's analysis operates on two levels. She considers specific attributes of each relocation-how such factors as place (rural vs urban), geography, local culture, and era shaped each initiative-but also how these initiatives operated in shared national and international contexts that saw the emergence of new concepts of democracy, government responsibility, and individual rights. Loo argues that collectively these relocation initiatives served to increase the reach and disciplinary power of the state while they also reflected a genuine optimism and commitment on the part of the state to ensuring that Canadians universally experience "the good life" - material equality and opportunity and a voice in their democracy.

Moved by the State adds to existing literature which has emphasized the lasting hardships created by relocation, as it seeks to understand the motives and policies of the architects of relocation schemes. With this approach, Loo challenges the concept of "the state" as monolithic and unknowable to consider instead how state programs were guided by well-intentioned people who were genuinely committed to improving the lives of the poorest Canadians. Loo's focus on these state actors offers a gateway to a more nuanced understanding of the complex (human) nature of "the state."

While Loo accepts that the people behind state relocation initiatives were animated by good intentions, Moved by the State is no hagiography. Loo makes clear that these individuals, while empathetic, operated "where the boundary between benevolence and oppression were easily crossed." (7) Although they viewed poor communities as being hamstrung by circumstances beyond their control (such as failing resources and geographic isolation), from their neoliberal vantage points they also believed that poor communities suffered of their own innate failings. Thus, state officials viewed Arctic 
Inuit as people psychologically damaged by colonialism, Newfoundlanders as being impeded by their inherent timidity, and people of the Gaspé region as victims of their parochialism. This emphasis on poor peoples' shortcomings ensured that tutelage was a central goal of relocation efforts and that the state committed to training relocated people to think and behave in (allegedly) new, modern, and progressive ways. This perspective, Loo explains, did not prevent state actors from recognizing the existence of larger structural issues, such as racism, but their overweening focus on fixing people disinclined them to seek remedies to wider structural problems.

Although Loo is critical of state actors, one wonders at times if she is critical enough. Loo argues that Africville's relocation was largely shaped by an antiracist, anti-segregationist, critique of Africville's historic marginalization. It was also the only relocated community to not include a community development initiative. Instead, grassroots organization was left to the community. Loo attributes this to the existence of the Halifax Human Rights Advisory Committee, an organization regarded by state actors as the voice of Afrciville. However, Loo also observes that in the decades following Africville's relocation, the emergent Black Power movement in Nova Scotia was contested by the state. This begs the question of whether racism-the state's fear of Black agency-might also have inspired the exclusion of community capacity building as part of relocation. Loo's observation that desegregation motivated Africville's relocation does not negate the possibility that racism also shaped the actions of the state; indeed, such complexity accords well with the nuance that is a great strength of this book.

Moved by the State emphasizes the work of state actors but does not neglect how communities themselves molded relocation policies. Loo demonstrates that communities shaped relocation in independently and in unanticipated ways that chagrined state organizers. For example, Newfoundland outporters with "surprising degree of latitude," (71) drew on claimed state resources even as they chose their own relocation destinations, often near their former communities. Similarly, Quebecers, frustrated by delays in implementation of relocation programs, undertook their own unsanctioned economic development initiatives. Poor communities were subject to state power, but they also shaped how that power was manifest, and Loo very successfully walks the line between recognizing both communities' agency and the extraordinary power of the state.

One of the most important insights into "the state" offered by Loo's innovative approach, is the way and the extent to which state relocation programs evolved over time. Moved by the State is rife with examples of how state relocation programs shifted, sometimes dramatically. For example, in the Arctic, government officials refined policy to make workplaces more accommodating of Inuit cultural practices. This followed a failed policy demanding Inuit adapt to capitalist imperatives, while Newfoundland relocation programs were watered down as a means of achieving greater compliance. State actors redirected relocation programs in response to interactions with communities, changing national and international contexts, and as they assessed local successes and failures. Loo thus reveals the fallacy of the monolithic state to show that it is as malleable as the people who comprise it.

In emphasizing the ideas, motives, and actions of state actors, Loo's work focusses largely on men who overwhelmingly served in this capacity, a focus that acts to downplay consideration of how 
gender shaped the creation and deployment of relocation policies. Loo's own evidence suggests that concepts of gender were very much at play in relocation programs. For example, Loo notes that Inuit craft programs that emerged as part of community development in the Arctic were designed to account for gendered concepts of work. Loo offers several examples of husband and wife teams whose research or other engagement was intended to address gendered considerations, and her characterization of the activism of Strathcona's Shirley Chan as "strategic flirtation" (160) hints at how gender was part of state-and community-strategizing. While Loo's work does not offer a sustained gendered analysis, it hints strongly at the potential utility of such an approach for understanding relocation specifically, and the nature of the post-war state in Canada more generally.

Tina Loo's Moved by the State is a meticulously researched and engagingly written book. It asks important questions of the nature of "the state" to demonstrate the complex factors that shaped not just post-war relocation initiatives but the wider expansion of the state in Canada.

Martha WALLS

Mount Saint Vincent University

\section{Esyllt W. Jones. Radical Medicine: the international origins of socialized health care in Canada (Winnipeg, MB: ARP Books 2019)}

RADICAL MEDICINE attempts a fundamental questioning of the origins of Canadian Medicare. A close reading of the book, however, reveals not so many radical aspects about medicine, health care, and their history in Canada. The reader will find plenty of qualifiers denoting "radical" and its derivatives, but most of them add little meaning to agents, events, or ideas. What is indeed radical about this history of health politics is a revisionist approach adopted by Esyllt Jones. Jones proposes to unravel the myth surrounding a historical development of Canadian Medicare by relating a so-called transnational story of leading advocates for an improved fair access to health care. Surprisingly enough, Jones' narrative is more regional and local that one would expect from the catchy title. It is evident in the book's thesis, as Jones "argues that the ideas and people that came together in Saskatchewan in the 1940s and early ' 50 s to build the CCF health program were part of a transnational, and on occasion explicitly internationalist, movement for greater health equality that percolated in the context of war, pandemic, and the October Revolution, then moved across the Atlantic world, reaching its apex at the close of World War II" (16). Despite being rather long and convoluted, this argument foregrounds how one province in Canada serves as a focus of discussion on the development of socialized systems of health care somewhat interconnected through time and space. This still begs the question as to whether sketches of regional policymaking prompted by certain political agendas, and biographical accounts of several historical figures may be necessary and sufficient to include the whole of Canada in a transnational movement for greater health equality.

This book makes a notable contribution to the history of grassroots engagement in health care movements. Surveying grassroots health advocacy during the interwar period in the Soviet Union, Great Britain, New Zealand, Australia, and Canada, Jones evaluates the proposition that a health-centred model of reform has become a gold standard for health proponents on the political left. Accordingly, the book's narrative traces how the idea of "socialized" or "state" medicine metamorphosed and took certain forms in the above countries due to historical 